\title{
Using the SYNTAX score to predict myocardial injury early after on-pump coronary artery bypass surgery: a single-centre experience analysis
}

\author{
Razan Al Namat ${ }^{1,2}$, Alexandru Burlacu ${ }^{2,3}$, Grigore Tinica ${ }^{2,4}$, Adrian Covic ${ }^{2,5}$, Florin Mitu M,2 $^{1,2}$ \\ ${ }^{1}$ Cardiovascular Rehabilitation Clinic, Iasi, Romania \\ 2“Grigore T. Popa” University of Medicine and Pharmacy, Iasi, Romania \\ ${ }^{3}$ Department of Interventional Cardiology, Cardiovascular Diseases Institute, Iasi, Romania \\ ${ }^{4}$ Department of Cardiovascular Surgery, Cardiovascular Diseases Institute, Iasi, Romania \\ ${ }^{5}$ Nephrology Clinic, Dialysis and Renal Transplant Center ‘C.I. Parhon' University Hospital, Iasi, Romania
}

Kardiochir Torakochir Pol 2020; 17 (2): 76-82

\begin{abstract}
Introduction: Marked isolated elevation of cardiac biomarkers (CK-MB, cardiac troponin I, heart-type fatty acid binding protein, hFABP) within 48 hours after coronary artery bypass surgery (CABG), even in the absence of electrocardiographic/ angiographic evidence of myocardial infarction (MI), indicates prognostically significant cardiac procedural myocardial injury. There are no data exploring the relationship between the complexity of coronary atherosclerotic burden and early post-CABG myocardial injury.

Aim: To analyse correlations and predictive strength of the SYNTAX score (SS) for early myocardial injury after on-pump CABG.

Material and methods: One hundred and twenty consecutive patients undergoing CABG were included in the analysis. We obtained data on demographics, medical history, cardiovascular risk factors and echocardiography. Cardiac biomarkers were assessed at 6 hours after CABG. Multivariate linear regression analysis was performed to evaluate independent variables correlated with cardiac biomarkers.

Results: The most significant predictor for myocardial injury was SS, strongly correlated with the rise of all cardiac biomarkers $(p<0.001)$. Hypertension and creatinine clearance were associated with cTnl and hFABP. Diabetes was corelated with hFABP. In a multivariate analysis including all significant predictors, SS remained an independent predictor for myocardial injury, strongly associated with hFABP $(p<0.001, \mathrm{OR}=5.79$, 95\% Cl: 3.59-7.98), cTnl ( $p<0.001$, OR $=6.49,95 \% \mathrm{Cl}: 4.78-$ 8.20), but not with CK-MB (95\% Cl: 0.61-1.07).

Conclusions: Defining myocardial injury as elevation of cardiac biomarkers between normal values and the cut-off for MI has a tremendous clinical significance as patients maintain high negative prognostic rates. SS could be used to predict postoperative rise of cardiac biomarkers, the correlation between SS and myocardial injury being very solid.
\end{abstract}

\section{Streszczenie}

Wprowadzenie: Znaczący izolowany wzrost stężeń biomarkerów kardiologicznych (CK-MB, troponiny sercowej I, białka wiążącego kwasy tłuszczowe typu sercowego - hFABP) w ciągu 48 godzin od operacji pomostowania aortalno-wieńcowego (CABG), nawet przy braku elektrokardiograficznych lub angiograficznych oznak zawału mięśnia sercowego (MI), stanowi istotny czynnik prognostyczny uszkodzenia mięśnia sercowego po zabiegu kardiologicznym. Brakuje danych obrazujących zależność między złożonością zmian miażdżycowych w obrębie tętnic wieńcowych a wczesnym uszkodzeniem mięśnia sercowego po zabiegu CABG.

Cel pracy: Analiza zależności i wartości predykcyjnej wyniku w skali SYNTAX (SS) we wczesnym uszkodzeniu mięśnia sercowego po zabiegu CABG z użyciem krążenia pozaustrojowego. Materiat i metody: Analizie poddano wyniki 120 pacjentów, u których przeprowadzono CABG. Zgromadzono dane demograficzne, zebrano wywiad i informacje o kardiologicznych czynnikach ryzyka oraz wykonano ocenę echokardiograficzną. Po 6 godzinach od CABG oznaczano stężenie biomarkerów kardiologicznych. Za pomocą wielowymiarowej regresji liniowej przeprowadzono ocenę zmiennych niezależnych na tle biomarkerów kardiologicznych.

Wyniki: Najbardziej istotnym czynnikiem predykcyjnym uszkodzenia mięśnia sercowego był wynik SS. Stwierdzono silną korelację ze wzrostem stężeń wszystkich biomarkerów kardiologicznych $(p<0,001)$. Wykazano zależność pomiędzy nadciśnieniem i klirensem kreatyniny a cTnl i hFABP. Stwierdzono także korelację między cukrzycą a hFABP. W analizie wieloczynnikowej obejmującej wszystkie istotne czynniki predykcyjne wynik SS okazał się niezależnym predyktorem uszkodzenia mięśnia sercowego, wykazując silną korelację $z$ hFABP ( $p<0,001 ;$ OR = 5,79; 95\% Cl: 3,59-7,98), cTnl $(p<0,001$; $\mathrm{OR}=6,49 ; 95 \% \mathrm{Cl}: 4,78-8,20)$ jednak brak korelacji z CK-MB (95\% Cl: 0,61-1,07).

Address for correspondence: Alexandru Burlacu MD, Cardiovascular Diseases Institute, 700503 Iasi, Romania, phone: +40 744488580,

e-mail: alburlacu@yahoo.com

Received: 4.12.2019, accepted: 25.04.2020. 
Key words: coronary artery bypass surgery, myocardial injury, SYNTAX score, predictor.
Wnioski: Zdefiniowanie uszkodzenia mięśnia sercowego jako wzrostu stężenia biomarkerów kardiologicznych od wartości prawidłowych do punktu odcięcia dla MI ma ogromną wartość kliniczną ze względu na utrzymanie wysokich ujemnych wartości prognostycznych u pacjentów. Ponieważ korelacja między SS a uszkodzeniem mięśnia sercowego jest bardzo znacząca, wyniki w skali SS mogą być wykorzystywane do prognozowania pooperacyjnego wzrostu stężenia biomarkerów kardiologicznych.

Stowa kluczowe: pomostowanie aortalno-wieńcowe, uszkodzenie mięśnia sercowego, wynik w skali SYNTAX, czynnik predykcyjny.

\section{Aim}

To date, there are no data exploring the relationship between the complexity of coronary atherosclerotic burden (e.g. SS) and early myocardial injury after CABG. Therefore, we sought to analyse the correlations and predictive strength of SS for early myocardial injury after onpump CABG (rise of CK-MB, CTnl or hFABP). If confirmed, SS could become a simple and efficient indicator for post-operative major adverse cardiac and cerebrovascular events (MACCE).

\section{Material and methods \\ Study population and inclusion criteria}

Between May 2015 and May 2017, one hundred and twenty consecutive patients undergoing elective CABG surgery in the Cardiovascular Diseases Institute from Iasi, Romania, were included in our analysis. All patients over 18 years of age scheduled for elective surgery were eligible for the study. Exclusion criteria were: 1) emergency/ off-pump CABG, 2) prior heart surgery, 3) concurrent valve surgery or aneurysmectomy, 4) prior myocardial infarction within the last 2 weeks, 5) severe coagulation abnormalities, 6) other concomitant procedures (MAZE procedure, tumours, pulmonary vein isolation). The time interval between coronary angiography and CABG was less than 90 days in all patients.

The surgery technique was decided by cardiac surgeons. The following variables were assessed: age, sex, cardiovascular risk factors (diabetes mellitus, arterial hypertension, chronic kidney disease), presence of heart failure assessed according to the New York Heart Association (NYHA), peripheral arterial disease, findings obtained in the preoperative transthoracic echocardiogram and coronary angiography. Laboratory tests analysed routine haematological and biochemical parameters (lipid panel, coagulation, inflammatory profile, renal and liver function). A post-operative echocardiographic evaluation was performed. All subjects agreed and signed an informed consent form. The study was approved by the "Grigore T. Popa" Iasi University Ethics Committee and was conducted according to the Declaration of Helsinki. No sex-based or racial/ethnic-based differences were present. 


\section{SYNTAX score}

The score calculator and therapeutic indications are available on the SS website (www.syntaxscore.com). Our analysis was performed retrospectively by two independent operators. Every significant inter-observer difference required a recalculation.

\section{Cardiac biomarkers}

We analysed myocardial injury related to CABG using 3 cardiac biochemical markers (CK-MB, cTn-I and hFABP). $\mathrm{hFABP}$ is a small cytosolic protein $(15 \mathrm{kDa})$ rapidly released in the circulation when membrane integrity is affected in response to cardiac ischaemia [16]. A sample of venous blood was obtained from the subjects at 6 hours after aortic unclamping. The cut-off value in early myocardial injury for hFABP was $6 \mathrm{ng} / \mathrm{l}$, as previously described in other studies $[17,18]$. Moreover, the cut-off levels for CK-MB (25 UI/I) and $\mathrm{cTn} I(0.01 \mathrm{ng} / \mathrm{ml})$ were chosen according to the guidelines for acute myocardial infarction [7]. The serum time to peak is shortest for the hFABP assay, with early rise specificity (6 hours, compared to 14-18 hours for CTn-I and 924 hours for $(K-M B)$, although serum levels increase as early as 30 minutes for hFABP (3-6 hours for cTn-I, 3-8 hours for CK-MB). Amongst the three cardiac markers, hFABP has the shortest half-life, returning to normal within $24 \mathrm{~h}$ [19].

\section{Surgical procedure}

The majority (99\%) of patients underwent on-pump bypass surgery (according to the internal protocol) by means of aorto-atrial cannulation and systemic hypothermia. The pump flows were fixed to maintain a cardiac index of more than $2.4 \mathrm{l} / \mathrm{min} / \mathrm{m}^{2}$. Myocardial protection was attained by intermittent antegrade administration of a hypothermic, St. Thomas' II cardioplegic solution. Pump circuit was primed with Ringer solution, heparin and mannitol. Any artery with an obstruction of more than $80 \%$ in the coronary angiography was grafted at the surgeon's convenience. Complete revascularisation was intended in all patients. Since the bilateral internal mammary artery (IMA) and radial artery for non-LAD targets have been shown to provide better patency rates than saphenous veins [20], particularly for the left coronary artery system, we used only arteries as coronary grafts: left IMA, right IMA and radial artery.

\section{Statistical analysis}

Continuous variables are expressed as mean \pm standard deviation and categorical data as number with percent frequency. Normality of variables' distribution was checked with the Shapiro-Wilk test. Independent $t$ test and 1-way ANOVA were performed for continuous variable comparisons. Nominal data were compared using the $\chi^{2}$ test. Stepwise multivariate linear regression analysis was performed to evaluate independent variables correlated with hFABP, CTn I and CK-MB. Statistical analyses were performed with SPSS 20.0 (IBM since version 19.0) and MedCalc (MedCalc Software bvba, Belgium). A two-tailed $p$-value $<0.05$ was considered significant.

\section{Results}

From 149 patients screened, 120 patients entered in the final analysis (8 could not provide signed informed consent, 11 had improper echo acquisitions, 10 with missing data). The mean age was $65.93 \pm 9.83$; 91 were male (75.2\%); 60.3\% $(n=73)$ were smokers and 98.3\% $(n=111)$ were hypertensive patients. In the hypertensive group, 90\% of patients were identified with moderate left ventricular concentric hypertrophy, with a mean left ventricular mass index of $143.31 \pm 46.40 \mathrm{~g} / \mathrm{m}^{2}$.

The majority of patients had at least a form of atherosclerotic disease, $62.8 \%(n=76)$ having a history of $\mathrm{MI}$, $2.9 \%$ of peripheral arterial disease, and $5 \%$ of stroke. The mean body mass index (BMI) was $29.4 \pm 3.02 \mathrm{~kg} / \mathrm{m}^{2}, 52.1 \%$ $(n=63)$ were diabetics, with a mean glycemia of 138.53 $\pm 57.43 \mathrm{mg} / \mathrm{dl}$, and total cholesterol of $181.54 \pm 46.33 \mathrm{mg} / \mathrm{dl}$. Eighty-one patients were admitted with NYHA class $\geq$ II $(67 \%)$ and had a mean left ventricular ejection fraction (LVEF) of $43.47 \pm 7.32 \%$.

After coronary angiography assessment, the mean SYNTAX score was $30.43 \pm 3.4$. After surgical myocardial revascularisation, early myocardial injury (defined as elevation of the serum cardiac biomarkers over the established thresholds) was detected in $97 \%$ of patients. The mean for hFABP was $68.5 \pm 46.1 \mathrm{ng} / \mathrm{ml}$, for troponin I was 0.75 $\pm 0.3 \mathrm{ng} / \mathrm{ml}$, and for CK-MB was $26.5 \pm 2.17 \mathrm{UI} / \mathrm{l}$.

All the baseline characteristics of the studied population are included in Table I.

In our study population we identified only two (out of 120 patients) acute early graft failures (needing reintervention/angioplasty). Due to the lack of transit time flow measurement (TTFM) device, and to logistical and infectious reasons (we could not transfer the patients to angio- $C T$ in the first 6-12 hours after CABG), we considered a graft failure in a patient with haemodynamic instability and high necrosis troponins/CK-MB).

Postoperative complications were as follows: atrial fibrillation/atrial flutter occurred in 23 (19.1\%) patients, with a peak incidence on the second and third postoperative days, 9 (7.5\%) patients developed renal dysfunction (1 patient required dialysis), 28 (23.3\%) patients developed pericardial effusion (2 patients developed a large effusion requiring emergency reopening of the median sternotomy).

Using linear regression model and univariate generalized linear model we assessed multiple variables for clinical prediction of myocardial injury (Table II). In the univariate analysis were the following variables: age, gender, BMI, smoking, MI, left ventricular mass index, history of peripheral arterial disease, history of stroke, diabetes, creatinine clearance, LVEF, and SYNTAX score.

The most significant predictor for myocardial injury was the SYNTAX score, being strongly correlated with the rise of all three cardiac biomarkers $(p<0.001$, OR $=66.36$, 95\% Cl: $4.17-8.55$ for hFABP, $p<0.001$, OR $=0.05,95 \% \mathrm{Cl}$ : $0.037-0.063$ for troponin I, and $p<0.01, \mathrm{OR}=0.21,95 \% \mathrm{Cl}$ : 0.105-0.325 for CK-MB) (Figure 1). Hypertension was asso- 
ciated only with the rise of hFABP $(p<0.017, \mathrm{OR}=26.28$, 95\% Cl: 4.76-47.81) and was weakly associated with troponin I ( $p<0.06, \mathrm{OR}=0.19,95 \% \mathrm{Cl}$ : 0.05-0.33). Creatinine clearance was strongly correlated with hFABP $(p<0.02$, $\mathrm{OR}=0.60,95 \% \mathrm{Cl}: 0.09-0.91)$ and troponin I $(p<0.02$, $\mathrm{OR}=0.01,95 \% \mathrm{Cl}:$ 0.002-0.03).

A multivariate analysis was conducted including all significant pre-operative clinical/paraclinical predictors from univariate correlations, except hypertension due to its high prevalence and lack of homogeneity among the studied population (which could affect the outcome of the multivariate analysis). After the adjustment of all clinical variables, SYNTAX score remained an independent predictor for myocardial injury, being strongly associated with the rise of hFABP ( $p<0.001, \mathrm{OR}=5.79,95 \% \mathrm{Cl}: 3.59-7.98)$ and troponin I $(p<0.001, \mathrm{OR}=6.49,95 \% \mathrm{Cl}: 4.78-8.20)$, but not with CK-MB (95\% Cl: 0.61-1.07) (Table III).

\section{Discussion}

To our knowledge, this study is the first one to demonstrate a strong connection between a higher SYNTAX score and early myocardial injury after on-pump CABG.

Since all patients received CABG, the SS was situated in the highest tertile category (values over 26) [21], a validating element for our cohort. Having in mind the "window" between 1 and 10 times the 99 $9^{\text {th }}$ percentile URL values (which means between "normal" values and "type $5 \mathrm{Ml}$ " cut-off), we do not refer to myocardial infarction after CABG, but to myocardial injury (7), which seems to be an important predictor of post-operative major cardiovascular events [8, 22].

Recently, ESC Joint Working Groups on Cardiovascular Surgery and the Cellular Biology of the Heart released a position paper on Peri-operative myocardial injury and infarction in patients undergoing CABG (7) acknowledging that "[...] isolated elevations of cardiac biomarkers below MI thresholds [...] may still be clinically relevant and prognostically significant."
Table I. Descriptive statistics of the study population

\begin{tabular}{|c|c|}
\hline Variables & $\begin{array}{c}\text { Overall } \\
\text { study group }\end{array}$ \\
\hline Age [years] mean \pm SD & $65.93 \pm 9.83$ \\
\hline Male gender, $n(\%)$ & $91(75.2)$ \\
\hline Body mass index $\left[\mathrm{kg} / \mathrm{m}^{2}\right]$ mean $\pm \mathrm{SD}$ & $29.4 \pm 3.03$ \\
\hline Smokers, $n(\%)$ & $73(60.3)$ \\
\hline Myocardial infarction, $n(\%)$ & $76(62.8)$ \\
\hline Hypertension, $n(\%)$ & $111(98.3)$ \\
\hline Left ventricular mass index $\left[\mathrm{g} / \mathrm{m}^{2}\right]$ mean $\pm \mathrm{SD}$ & $143.31 \pm 46.40$ \\
\hline Peripheral arterial disease, $n(\%)$ & $32(2.9)$ \\
\hline Stroke, $n(\%)$ & $6(5)$ \\
\hline Diabetes, $n(\%)$ & $63(52.1)$ \\
\hline Glycemia $[\mathrm{mg} / \mathrm{dl}]$ mean $\pm \mathrm{SD}$ & $138.53 \pm 57.43$ \\
\hline Total cholesterol [mg/dl] mean \pm SD & $181.54 \pm 46.34$ \\
\hline $\mathrm{LDL}$ cholesterol $[\mathrm{mg} / \mathrm{dl}]$ mean $\pm \mathrm{SD}$ & $144.26 \pm 30.71$ \\
\hline $\mathrm{HDL}$ cholesterol [mg/dl] mean $\pm \mathrm{SD}$ & $40 \pm 21.27$ \\
\hline Triglycerides $[\mathrm{mg} / \mathrm{dl}]$ mean $\pm \mathrm{SD}$ & $136 \pm 56.94$ \\
\hline Aspartate aminotransferase $[\mathrm{U} / \mathrm{I}]$ mean $\pm \mathrm{SD}$ & $27.5 \pm 26.24$ \\
\hline Glutamic-oxaloacetic transaminase [U/l] mean \pm SD & $30 \pm 37.15$ \\
\hline Gamma-glutamyltranspeptidase [U/l] mean \pm SD & $33.50 \pm 24.32$ \\
\hline Fibrinogen $[\mathrm{mg} / \mathrm{dl}]$ mean $\pm \mathrm{SD}$ & $600 \pm 174.4$ \\
\hline Hs C reactive protein $[\mathrm{mg} / \mathrm{l}]$ mean $\pm \mathrm{SD}$ & $3 \pm 2.96$ \\
\hline Chronic kidney disease, $n(\%)$ & $7(5.8 \%)$ \\
\hline Creatinine clearance $\left[\mathrm{ml} / \mathrm{min} / 1.73 \mathrm{~m}^{2}\right]$ mean $\pm \mathrm{SD}$ & $60.83 \pm 16.23$ \\
\hline NYHA class $\geq I I, n(\%)$ & $81(67 \%)$ \\
\hline LVEF $(\%)$ mean \pm SD & $43.47 \pm 7.33$ \\
\hline Number of bypass, mean \pm SD & $1.64 \pm 0.9$ \\
\hline Aortic cross-clamp duration [min] & $73 \pm 21$ \\
\hline SYNTAX score $(n)$ mean \pm SD & $30.43 \pm 3.40$ \\
\hline $\operatorname{hFABP}(n)$ mean $\pm \mathrm{SD}$ & $68.45 \pm 46.08$ \\
\hline cTroponin I $(n)$ mean \pm SD & $0.744 \pm 0.30$ \\
\hline CK-MB, mean \pm SD & $26.46 \pm 2.17$ \\
\hline
\end{tabular}

NYHA - New York Heart Association, LVEF - left ventricular ejection fraction, hFABP - heart-type fatty acid binding protein.

Table II. Predictors of myocardial injury by univariate analysis of the study population

\begin{tabular}{lccccccccc} 
& \multicolumn{3}{c}{ hFABP } & \multicolumn{7}{c}{ CTroponin I } & \multicolumn{2}{c}{ CK-MB } \\
\cline { 2 - 11 } Age & P-value & OR & $95 \% \mathrm{Cl}$ & P-value & OR & $95 \% \mathrm{Cl}$ & P-value & OR & $95 \% \mathrm{Cl}$ \\
\hline Gender & 0.406 & - & - & 0.574 & - & - & 0.086 & - & - \\
\hline Body mass index & 0.347 & - & - & 0.652 & - & - & 0.832 & - & - \\
\hline Smoking & 0.392 & - & - & 0.578 & - & - & 0.835 & - & - \\
\hline Myocardial infarction & 0.183 & - & - & 0.306 & - & - & 0.857 & - & - \\
\hline Hypertension & 0.075 & - & - & 0.065 & - & - & 0.369 & - & - \\
\hline Left ventricular mass index & 0.017 & $\mathbf{2 6 . 2 8}$ & $\mathbf{4 . 7 6 - 4 7 . 8 1}$ & 0.06 & 0.195 & $0.05-0.33$ & 0.709 & - & - \\
\hline Peripheral arterial disease & 0.241 & - & - & 0.27 & - & - & 0.191 & - & - \\
\hline Stroke & 0.973 & - & - & 0.909 & - & - & 0.90 & - & - \\
\hline Diabetes mellitus & $\mathbf{0 . 0 1 8}$ & $\mathbf{1 9 . 9 1}$ & $\mathbf{3 . 5 5 - 3 6 . 3 0}$ & 0.109 & - & - & 0.91 & - & - \\
\hline Creatinine clearance & $\mathbf{0 . 0 2 0}$ & $\mathbf{0 . 6 0}$ & $\mathbf{0 . 0 9 - 0 . 9 1}$ & $\mathbf{0 . 0 2 0}$ & $\mathbf{0 . 0 1 2}$ & $\mathbf{0 . 0 0 2 - 0 . 0 3}$ & 0.6 & - & - \\
\hline LVEF & 0.279 & - & - & 0.910 & - & - & 0.284 & - & - \\
\hline SYNTAX & $<0.001$ & $\mathbf{6 . 6 3 6 6}$ & $\mathbf{4 . 1 7 - 8 . 5 5}$ & $<0.001$ & $\mathbf{0 . 0 5 0}$ & $\mathbf{0 . 0 3 7 - 0 . 0 6 3}$ & $<0.001$ & $\mathbf{0 . 2 1 5}$ & $\mathbf{0 . 1 0 5 - 0 . 3 2 5}$ \\
\hline
\end{tabular}

LVEF - left ventricular ejection fraction, hFABP - heart-type fatty acid binding protein. Bold values are statistically significant. 

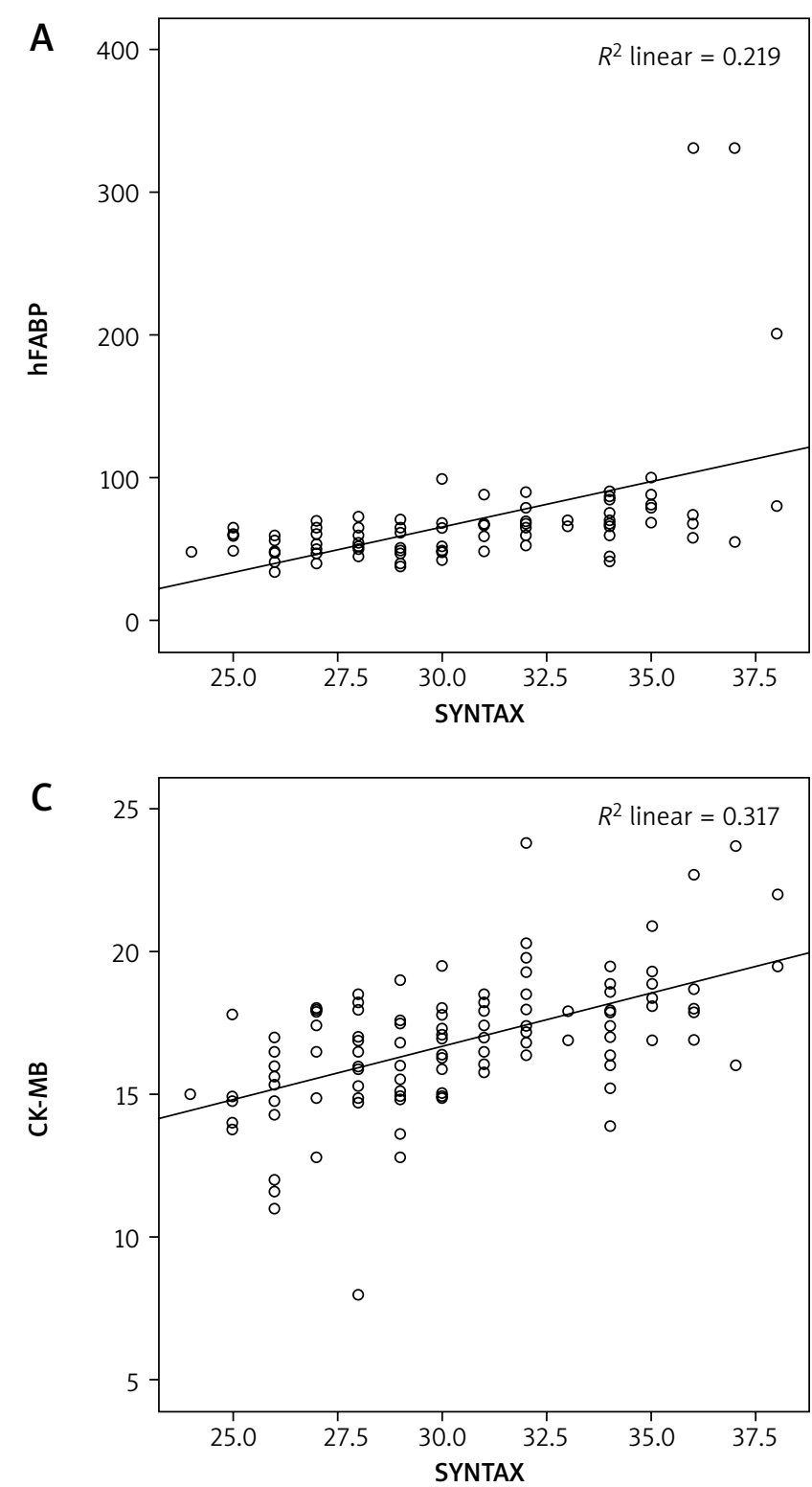

Apparently, this event of myocardial injury occurs due to a great number of causes different from obvious graft failure or significant ischaemic syndrome on native arteries: arterial graft spasm/micro-embolism, tachyarrhythmia, cardiogenic/hypovolaemic shock, severe respiratory failure, severe anaemia, left ventricular hypertrophy, inadequate cardioprotection from cardioplegia, cardiac handling during surgery, surgical myectomy, inflammatory injury due to cardiopulmonary bypass, heart failure, severe pulmonary embolism, sepsis, or renal failure [7, 23].

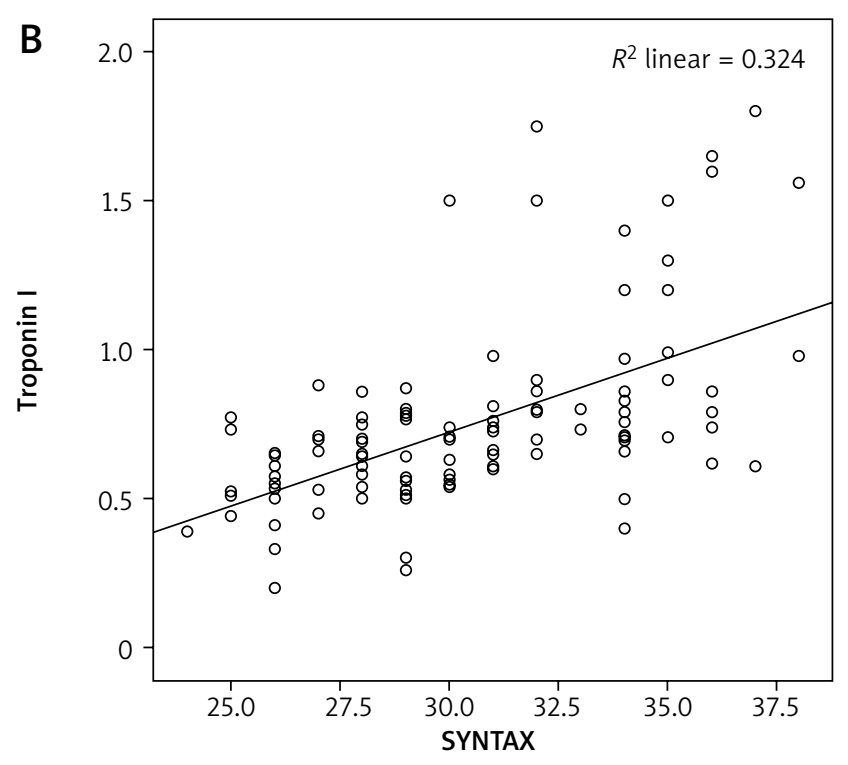

Figure 1. Graphical representation of univariate analysis of SYNTAX score and hFABP $(A)$, troponin I (B) and CK-MB (C) by linear regression models. $P$-values for all, 0.001 . $\mathrm{OR}=5.79,6.49$ and 0.844 respectively

One of the strongest points of our study is that we assessed two traditional markers (CK-MB and CTnI) and a "newer" cardiac bio-marker, hFABP. We checked for concordance and observed that at 6 hours post-operatively almost all patients manifested cTnl and hFABP values over 10 times normal values, even if they had unchanged ECG and echo.

This was an expected observation since other studies reported it for $\mathrm{CTnI}[7,22,24]$. On the other hand, it was too early to detect high values of CK-MB (which most presented as "near-normal" at 6 hours, being not "too

Table III. Independent predictors of myocardial injury after multivariate analysis

\begin{tabular}{|c|c|c|c|c|c|c|c|c|c|}
\hline \multirow[t]{2}{*}{ Variables } & \multicolumn{3}{|c|}{ hFABP } & \multicolumn{3}{|c|}{ cTroponin I } & \multicolumn{3}{|c|}{ CK-MB } \\
\hline & $P$-value & OR & $95 \% \mathrm{Cl}$ & $P$-value & OR & $95 \% \mathrm{Cl}$ & $P$-value & OR & $95 \% \mathrm{Cl}$ \\
\hline Diabetes mellitus & 0.072 & 0.53 & $0.31-0.89$ & 0.31 & - & - & 0.82 & - & - \\
\hline Creatinine clearance & 0.08 & 0.62 & $0.10-0.16$ & 0.12 & - & - & 0.668 & - & - \\
\hline SYNTAX & $<0.001$ & 5.79 & $3.59-7.98$ & $<0.001$ & 6.49 & $4.78-8.20$ & $<0.001$ & 0.844 & 0.61-1.07 \\
\hline
\end{tabular}


elevated", between $1 \times$ and $2 \times$ times the $99^{\text {th }}$ percentile URL values). For each 1 point increase in SS we found a significant elevation in myocardial injury (as confirmed by two bio-markers), supporting good discriminatory power for SS.

A prospective observational study published in 2007 in the Journal of American College of Cardiology ascertained that hFABP provides direct evidence not only of acute myocyte necrosis, but also of myocardial ischaemia, better than cTnl [25]. This means that even if there is no evidence of important cardiac necrosis, repeated intervals of myocardial ischaemia (during the CABG surgery procedure) could be quantified through hFABP values - expressed as a myocardial injury parameter. Moreover, the same study mentioned that hFABP values were predictive for long-term mortality after acute coronary syndromes, while identifying high-risk patients in a manner that is additive to the GRACE clinical risk factors, troponin, and hs-CRP, possibly as a result of pinpointing the occurrence of myocardial ischaemia with/ without necrosis [25].

Another recent study validated the peri-operative hFABP use for risk stratification of acute kidney injury and mortality following cardiac surgery [26]. Thus, the strong correlation between a high SS and hFABP at 6 hours demonstrated by our study could be very important for preCABG stratification and selection of patients prone to renal failure. It is a simple way to select those patients with a SYNTAX over the value of 30 and expect a higher hFABP, acute renal complications and significantly more postoperatory cardiovascular adverse events. This information could be used to re-assess CABG protocols and algorithms (on-pump time, number of grafts, a prompt correction of anaemia), and thus to influence the negative prognosis of such patients.

Moreover, we consider that the SYNTAX score could be used to select patients who can benefit from special cardioprotective strategies: ischaemic preconditioning (IPC), ischaemic post-conditioning (IPost) and remote ischaemic preconditioning (RIPC) [7]. A number of smaller studies have reported reduced myocardial damage with IPC, IPost, and RIPC [27]. These studies used cardiac bio-marker assessment (CK, CK-MB, and CTn) to evaluate the size of myocardial injury and to assess the cardioprotective efficacy of novel therapies. If patients at high risk of myocardial injury could be identified before CABG, "customised management pathways comprising more aggressive monitoring, investigations and/or treatment approaches may result in improved clinical outcomes" [7].

The low total number of patients in our study group represents a limitation, as well as possible referral bias, given that the research was performed in a single centre. It would have been more accurate to assess all three bio-markers at three different post-CABG time points (at 6, 12 and 24 hours respectively). Moreover, it would be interesting to include on-pump/clamping time in the analysis and also to perform a one- or two-year post-CABG follow-up.

\section{Conclusions}

Since the CABG procedure involves a great number of resources, every effort should focus on minimizing postsurgery complications and outcomes. Thus, defining myocardial injury as elevation of cardiac troponins (cardiac bio-markers) between normal values and the 10x cut-off for $\mathrm{MI}$ has tremendous clinical significance as this category of patients maintains high negative prognostic rates. We demonstrated that the SYNTAX score can also be used to predict a post-operative rise of cardiac bio-markers (namely, hFABP and cTn I), the correlation between SYNTAX and myocardial injury being very solid.

\section{Acknowledgments}

AB: was supported by the Romanian Academy of Medical Sciences and European Regional Development Fund, MySMIS 107124: Funding Contract 2/Axa 1/31.07.2017/ 107124 SMIS

\section{Disclosure}

Authors report no conflict of interest.

\section{References}

1. Neumann FJ, Sousa-Uva M, Ahlsson A, et al. 2018 ESC/EACTS Guidelines on myocardial revascularization. Eurolntervention 2019; 14: 1435-1534.

2. Sianos G, Morel MA, Kappetein AP, et al. The SYNTAX Score: an angiographic tool grading the complexity of coronary artery disease. Eurolntervention 2005; 1: 219-227.

3. Capodanno D, Di Salvo ME, Cincotta G, et al. Usefulness of the SYNTAX score for predicting clinical outcome after percutaneous coronary intervention of unprotected left main coronary artery disease. Circulation Cardiovasc Interv 2009; 2: 302-308

4. Kemp M, Donovan J, Higham H, Hooper J. Biochemical markers of myocardial injury. Br J Anaesthesia 2004; 93: 63-73.

5. Cho Y, Shimura S, Aki A, et al. The SYNTAX score is correlated with long-term outcomes of coronary artery bypass grafting for complex coronary artery lesions. Interact Cardiovasc Thorac Surg 2016; 23: 125-132.

6. Qi X, Xu M, Yang H, et al. Comparing mortality and myocardial infarction between coronary artery bypass grafting and drug-eluting stenting in patients with diabetes mellitus and multivessel coronary artery disease: a meta-analysis. Arch Med Sci 2014; 10: 411-418.

7. Thielmann M, Sharma V, Al-Attar N, et al. ESC Joint Working Groups on Cardiovascular Surgery and the Cellular Biology of the Heart Position Paper: Perioperative myocardial injury and infarction in patients undergoing coronary artery bypass graft surgery. Eur Heart J 2017; 38: 2392-2407.

8. Thygesen K, Alpert JS, Jaffe AS, et al. Fourth Universal Definition of Myocardial Infarction (2018). Circulation 2018; 138: e618-e651.

9. Babuin L, Jaffe AS. Troponin: the biomarker of choice for the detection of cardiac injury. Canad Med Assoc J 2005; 173: 1191-1202.

10. Holmvang L, Jurlander B, Rasmussen C, et al. Use of biochemical markers of infarction for diagnosing perioperative myocardial infarction and early graft occlusion after coronary artery bypass surgery. Chest 2002; 121: 103-11.

11. Bignami E, Landoni G, Crescenzi G, et al. Role of cardiac biomarkers (troponin I and (K-MB) as predictors of quality of life and long-term outcome after cardiac surgery. Ann Cardiac Anaesthesia 2009; 12: 22-26.

12. Domanski MJ, Mahaffey K, Hasselblad V, et al. Association of myocardial enzyme elevation and survival following coronary artery bypass graft surgery. JAMA 2011; 305: 585-591.

13. Petaja L, Salmenpera M, Pulkki K, Pettila V. Biochemical injury markers and mortality after coronary artery bypass grafting: a systematic review. Ann Thorac Surg 2009; 87: 1981-1992.

14. Muehlschlegel JD, Perry TE, Liu KY, et al. Heart-type fatty acid binding protein is an independent predictor of death and ventricular dysfunction after coronary artery bypass graft surgery. Anesthesia Analgesia 2010; 111: 1101-1109. 
15. Petzold T, Feindt P, Sunderdiek U, et al. Heart-type fatty acid binding protein ( $\mathrm{hFABP}$ ) in the diagnosis of myocardial damage in coronary artery bypass grafting. Eur J Cardiothorac Surg 2001; 19: 859-864.

16. Carless DR, Wnek M, Knox C, et al. Clinical and analytical evaluation of an immunoturbidimetric heart-type fatty acid-binding protein assay. Scand J Clin Labor Investig 2013; 73: 48-53.

17. Pelsers MM, Hermens WT, Glatz JF. Fatty acid-binding proteins as plasma markers of tissue injury. Clin Chim Acta 2005; 352: 15-35.

18. Nagahara D, Nakata T, Hashimoto A, et al. Early positive biomarker in relation to myocardial necrosis and impaired fatty acid metabolism in patients presenting with acute chest pain at an emergency room. Circ J 2006; 70: 419-425.

19. McCann CJ, Glover BM, Menown IB, et al. Novel biomarkers in early diagnosis of acute myocardial infarction compared with cardiac troponin T. Eur Heart 2008; 29: 2843-2850

20. Benedetto U, Raja SG, Albanese A, et al. Searching for the second best graft for coronary artery bypass surgery: a network meta-analysis of randomized controlled trials. Eur J Cardiothorac Surg 2015; 47: 59-65.

21. Holzhey DM, Luduena MM, Rastan A, et al. Is the SYNTAX score a predictor of long-term outcome after coronary artery bypass surgery? Heart Surgery Forum 2010; 13: E143-E148.
22. Wang TK, Stewart RA, Ramanathan T, et al. Diagnosis of MI after CABG with high-sensitivity troponin T and new ECG or echocardiogram changes: relationship with mortality and validation of the universal definition of MI. Eur Heart J Acute Cardiovasc Care 2013; 2: 323-333.

23. Yau JM, Alexander JH, Hafley G, et al. Impact of perioperative myocardial infarction on angiographic and clinical outcomes following coronary artery bypass grafting (from PRoject of Ex-vivo Vein graft ENgineering via Transfection [PREVENT] IV). Am J Cardiol 2008; 102: 546-551.

24. Brener SJ, Lytle BW, Schneider JP, et al. Association between CK-MB elevation after percutaneous or surgical revascularization and three-year mortality. J Am Coll Cardiol 2002; 40: 1961-1967.

25. Kilcullen N, Viswanathan K, Das R, et al. Heart-type fatty acid-binding protein predicts long-term mortality after acute coronary syndrome and identifies high-risk patients across the range of troponin values. J Am Coll Cardiol 2007; 50: 2061-2067.

26. Schaub JA, Garg AX, Coca SG, et al. Perioperative heart-type fatty acid binding protein is associated with acute kidney injury after cardiac surgery. Kidney Int 2015; 88: 576-583.

27. Heusch G. Cardioprotection: chances and challenges of its translation to the clinic. Lancet 2013; 381: 166-175. 